\title{
OPEN Author Correction: Characterization and printability of Sodium alginate -Gelatin hydrogel for bioprinting NSCLC co-culture
}

\section{Arindam Mondal, Aragaw Gebeyehu, Mariza Miranda, Divya Bahadur, Nilkumar Patel, Subhramanian Ramakrishnan, Arun K. Rishi \& Mandip Singh}

Correction to: Scientific Reports https://doi.org/10.1038/s41598-019-55034-9, published online 27 December 2019

The Acknowledgements section in this Article is incomplete.

“This project was supported by NSF-CREST center for Complex Material Design for Multidimensional Additive processing (CoManD) award \# 1735968.”

should read:

“This project was supported by NSF-CREST center for Complex Material Design for Multidimensional Additive processing (CoManD) award \# 1735968, and FAMU center of Health disparities research grant, RCMI 5U54MD007582-35 from NIH."

(c) Open Access This article is licensed under a Creative Commons Attribution 4.0 International Cicense, which permits use, sharing, adaptation, distribution and reproduction in any medium or format, as long as you give appropriate credit to the original author(s) and the source, provide a link to the Creative Commons license, and indicate if changes were made. The images or other third party material in this article are included in the article's Creative Commons license, unless indicated otherwise in a credit line to the material. If material is not included in the article's Creative Commons license and your intended use is not permitted by statutory regulation or exceeds the permitted use, you will need to obtain permission directly from the copyright holder. To view a copy of this license, visit http://creativecommons.org/licenses/by/4.0/.

(c) The Author(s) 2020 